\title{
Taxation and Dividend Payout: The Case of the Republic of Serbia
}

DOI: 10.7595/management.fon.2021.0016

\begin{abstract}
:
Research Question: The paper investigates the relationship between taxation and dividend payout decisions of companies in the Republic of Serbia. Motivation: Including taxation in dividend policy discussion may allow for better understanding of decisions of companies to pay dividends. Prior worldwide research results on the impact of taxation on dividend policy are inconclusive, often contradicting and cannot be universally accepted. Despite abundant research in previous decades, the key drivers of dividend policy of companies are still unknown and there exists a so-called dividend puzzle. In addition, the research on dividend policy of companies in transition countries (including the Republic of Serbia) is relatively scarce. On the other hand, research in transition countries is important as transition countries have a significantly lower level of capital market efficiency and liquidity, having a lower number of joint stock companies and a lower number of companies that regularly pay dividends. Idea: Since tax burden may be a significant obstacle for companies to pay dividends, it may be relevant to research into whether corporate income tax burden has an impact on dividend payout ratio of companies, as well as the impact of dividend tax that shareholders have to pay on the dividend payout. Data: The study captured 23 companies listed on the Belgrade Stock Exchange between 2013 and 2018 that paid dividends in at least one year. In total, the research involved 92 dividend payouts. Research data have been retrieved from the Business Registers Agency of the Republic of Serbia. Tools: Research hypotheses are tested using EViews and IBM SPPS software. Statistical methods included descriptive statistics, correlation and regression analysis, as well as non-parametric statistical tests for independent samples. Findings: The analysis shows that corporate income tax does not impact a dividend payout ratio of companies, indicating that companies do not consider the corporate income tax when deciding on dividends, mostly due to the effective tax rates being considerably lower than the statutory tax rate of $15 \%$. Also, statistical tests show that the dividend tax does not impact the dividend payout ratio, as there is no significant difference in the dividend payout ratio between companies whose largest shareholder is high taxed and companies whose largest shareholder is low taxed. Contribution: Research results may be of interest for company management when designing the dividend policy as well as for investors when deciding on shares investment in accordance with their tax preferences.
\end{abstract}

Keywords: dividend, dividend policy, dividend payout ratio, corporate income tax, dividend tax.

JEL Classification: G30, G35, H24, H25.

\section{Introduction}

The dividend policy represents an important area of modern corporate finance. Contrary to the traditional dividend irrelevance theory, most managers believe that the dividend policy influences company value (Baker \& Powell, 1999). The dividend policy problem is further complicated with cross-country differences in tax systems and different tax treatment of dividends and capital gains. In addition, the relation between dividends and share repurchase (as two alternative ways of cash distribution to shareholders, usually with different tax effects) has been analyzed in the last two decades (Grullon \& Michaely, 2002; Brown, Liang \& Weisbenner, 2007).

In the Republic of Serbia (RS), corporate income tax and dividend tax may be important obstacles to dividend payment - there is a double taxation system imposed since income is first taxed at the company level 
(corporate income tax) followed by a taxation of income portion distributed to shareholders (dividend tax). However, it is worth noting that certain groups of investors are, at least partially, exempted from dividend tax.

Research on dividend policy of companies in the RS is limited due to lack of stock market development. Serbian capital market is also characterized by the lack of liquidity (Zivkovic \& Minovic, 2010). Considering the bankocentric financial system of the RS, the role of capital market in company financing is minor (Stakic, Jovancai \& Kapor, 2016). In addition, a number of public stock companies in the RS is continuously declining with only a few companies paying dividends regularly.

The research subject of this paper is the dividend policy of companies in the RS. The objective of the research is to examine the impact of corporate income tax and dividend tax on dividend policy of companies in the RS. As a proxy for dividend policy, used in the paper is the dividend payout ratio (DPR) - relation between dividend per share and earnings per share. In line with defined research subject and objective, the following research hypotheses are tested in the paper:

$\mathrm{H}_{1}$ : Corporate income tax expense has a statistically significant negative impact on the DPR of companies in the RS.

$\mathrm{H}_{2}$ : Dividend tax paid has a statistically significant impact on DPR of companies in the RS.

To authors' knowledge, this is the first research in the RS that analyzes the dividend policy from the tax aspect. Although numerous studies have been conducted on determinants of dividend policy in emerging markets and developing countries, the impact of taxation on dividend decisions of companies in these countries is usually not examined (for example Mehta, 2012; Maniagi et al., 2013; Benavides, Berggrun \& Perafan, 2016; Bostanci, Kadioglu \& Sayilgan, 2018; Franc-Dabrowska, Madra-Sawicka \& Ulrichs, 2020). In other words, only few studies include taxation as a potential explanatory variable of dividend payout in these countries (for example Amidu \& Abor, 2006; Singla \& Samanta, 2019).

The research contributes to the existing foreign results (primarily from developed countries) on the impact of taxation on dividend policy. The research results may be of interest for company management when designing the dividend policy as well as for investors when deciding on shares investment in accordance with their tax preferences.

Besides introduction and conclusion, the paper consists of four parts. He first part presents a tax aspect of dividend policy theories. The legal aspect of dividend taxation in the RS is shown in the second part, while in the third part the relation between taxation and decision on paying dividends is analyzed. Research methodology and results are presented in the fourth part.

\section{Theoretical Background: Taxation and Dividend Policy}

A number of theoretical explanations of dividend policy have been noted in the past decades. However, there are not many studies that largley deal with the impact of taxation on dividend policy.

Some of the first dividend policy theories have not significantly discussed thetaxation factor. The bird-in-thehand theory argues that investors prefer dividend payment to capital gains due to the uncertainty of achieving capital gains in the future. On the other hand, Modigliani-Miller theory says that, assuming market perfection, dividend policy does not impact company value. However, at that time, there were indications of the impact of taxation on dividend policy. Thus, Gordon (1959) allows the impact of different tax treatment of dividends and capital gains on investors preference to non-dividend paying companies. Miller \& Modigliani (1961) stress that different tax treatment of dividends and capital gains is the most important market imperfection requiring further research attention.

The theory of tax preferences is a theory fully based on the taxation factor. Although there are important cross-country differences in tax systems, capital gains are tax-favoured compared to dividend payment in most countries. Therefore, investors prefer shares of non-dividend paying companies:

- if capital gains tax is paid at the moment of share sale, while dividend tax is paid at the moment of dividend payment - considering time value of the money, it is possible to achieve considerable tax savings when preferring capital gains and

- if capital gains tax rate is lower than dividend tax rate or if it is possible to offset capital losses with capital gains. 
Tax preferential treatment of capital gains may also favour share repurchases over dividend payments as share repurchases are taxed on the basis of capital gains realized. For instance, Grullon \& Michaely (2002) show that share repurchases have become highly popular among US companies, since companies finance their share repurchases with funds that otherwise would have been used to dividend payments.

Extension of tax preference theory can be found in explanation of different clienteles, i.e., different groups of investors. The clientele effect arises as a result of market imperfections, such as taxation or transaction costs. According to tax clientele effect, high-taxed investors (investors in higher tax bracket) prefer shares of non-dividend paying companies and vice versa. Some of the first authors that supported tax clientele effect with empirical evidence were Litzeberger \& Ramaswamy (1979), Chaplinsky \& Seyhun (1990) and Alli, Khan \& Ramirez (1993).

Out of the recent research, Dhaliwal, Erickson \& Trezevant (1999) analyze listed companies in the US and find that the share of low taxed investors increases in companies that declare dividend payment along with the decline of share of high taxed investors. Dahlquist, Robertsson \& Rydqvist (2014) also support tax clientele effect finding that certain groups of investors are not interested in investing in shares of Swedish dividend paying companies due to unfavorable tax treatment of dividends. Maier \& Schanz (2016) analyze taxation of dividends and capital gains in European Union and conclude that capital gains are tax-favored in comparison with dividends for individual investors, while the findings are contrary for corporate investors.

The catering theory is one of the most recent dividend policy theories (Denis \& Osobov, 2008). Baker \& Wurgler (2004) argue that managers design dividend policy in accordance with investors preferences. Thus, management initiates dividend payment when investors value dividend paying companies more than nondividend paying companies. Therefore, assuming rational market participants, the company pays dividends when its shareholders want it, i.e., when shareholders are low taxed. Desai \& Jin (2011) show that rational investors pay attention to tax effects of the company dividend policy, but also that management takes into consideration tax preferences of investors when deciding on dividend payment.

Chetty \& Saez (2010) tie dividend taxation with agency theory, i.e., relation between managers and shareholders. The dividend payment reduces cash flow under management control, reducing also chances for opportunistic behaviour of managers. However, unfavorable tax treatment of dividends can induce profit retaining, which can be used by managers to undertake unprofitable investments. These authors argue that the impact of dividend taxation on such welfare loss is higher than the impact of corporate income tax. Jacob \& Michaely (2017) conclude that taxation factor has an important impact on the company dividend policy, with the fact that such an impact declines if there are conflicts between shareholders and management or conflicts among shareholders.

The key reason for the unfavorable tax treatment of dividends can be found in their double taxation. In classical double taxation systems, firstly, there is taxation of company income, followed by taxation of income portion paid as dividends to shareholders. This problem has been reduced with integrated tax systems in which double taxation is, partially or wholly, eliminated. Therefore, the finding of Balachandran, Khan, Mater \& Theobald (2019) that it is more probable the company will pay dividends in imputation tax system is not surprising.

\section{Taxation and Dividend Decision}

\subsection{Corporate income tax expense and dividend payout ratio}

Corporate income tax expense represents reduction in profit available for distribution to shareholders. According to International Accounting Standard 12 - Income Taxes, applied by public stock companies in the RS, corporate income tax expense consists of current tax expense and deferred tax expense (benefit). Current tax expense refers to income tax payable for reporting period, while deferred tax expense (benefit) represents a non-cash income statement position arising as a result of temporary differences between values of assets and liabilities in financial and tax evidence as well as unused tax credits and tax losses carryforward.

At the same time, corporate income tax expense offers an opportunity to managers to adjust income in line with the desired dividend policy. Dhaliwal, Gleason \& Mills (2004) note that company management can inflate deferred tax benefit in order to increase profitability and make a basis for higher dividend payment. This particularly refers to situations when the company did not achieve the target profit and misuses deferred tax to achieve it. On the other hand, deferred income tax can serve as an instrument for income smoothing (Frank \& Rego, 2006), making a base for stable dividend policy. 
Corporate income tax burden is usually proxied with effective tax rates. Using income statement data, it is possible to calculate two effective tax rates, defined by Hanlon \& Heitzman (2010): Accounting tax rate (corporate income tax expense divided by pre-tax income) and Current tax rate (current tax expense divided by pre-tax income).

Since corporate income tax expense is a negative income statement item, it is rational to assume that DPR is, ceteris paribus, lower in companies with higher corporate income tax burden. However, scarce empirical research did not support such assumption - on the contrary, Amidu \& Abor (2006) and Gill, Biger \& Tibrewala (2010) studied Ghanaian and US companies, respectively, and found that DPR was significantly higher in companies with higher corporate income tax burden. Singla \& Samanta (2019) do not find the significant impact of corporate tax expense on dividend payout of construction companies in India. Such findings indicate that companies do not consider pre-tax income and corporate income tax expense, but only net income, when deciding on dividend policy.

\subsection{Ownership type and dividend payout ratio}

Prior empirical research shows that ownership concentration, at least partially, influences dividend policy. Harada \& Nguyen (2011) show that ownership concentration in Japanese companies implies lower dividends, while Mancinelli \& Ozcan (2006) find a decline in dividend payments of Italian companies with increase in voting rights of the largest shareholder. On the other hand, Chen, Cheung, Stouraitis \& Wong (2005) find only partial relation between concentrated ownership of family companies in Hong Kong and dividend payments of these companies.

Ownership structure can also influence dividend payments. Short, Zhang \& Keasey (2002) find positive relation between share of institutional investors in ownership and dividend payments of British companies. Also, in case of British companies, Khan (2006) finds positive relation between the share of insurance companies in ownership and dividend payments and negative relation between the share of individuals in ownership and dividend payments.

From the tax aspect, it is important to know the tax bracket of the largest shareholder, i.e., dividend tax rate applied on the largest shareholder. According to the RS regulation, a shareholder can be, on the one side, exempt from dividend tax (in the case of resident legal entity) and, on the contrary, taxed at maximum dividend tax rate of $20 \%$ (in the case of non-resident legal entity that is resident of the country that did not sign double tax treaty with the RS). In this regard, it is rational to assume that DPR is higher whenthe largest shareholder is in lower tax bracket and vice versa.

There is no significant prior research examining the relation between tax bracket of largest shareholder and DPR. However, some research may refer to tax brackets. Short et al. (2002) and Khan (2006) note that institutional investors are tax-favored dividend payees in Great Britain, so it is possible that a positive relation between the share of institutional investors in ownership and dividend payments is a result of tax factors.

\section{Tax Treatment of Dividends in the Republic of Serbia}

\subsection{Legal aspect of dividend taxation}

Dividend taxation in the RS is conducted in accordance with the double taxation system. However, details of dividend taxation depend on whether the dividend payee is individual or legal entity and whether the dividend payee is a resident or non-resident of the RS.

Dividends that individuals receive are taxed in accordance withthe Personal Income Tax Law (The Official Gazette of the RS, no. 95/2018). According to article 61, dividends that individuals receive are considered as capital income, taxed at $15 \%$ rate applied on gross dividend.

In general, dividends that non-resident individuals receive are also taxed at $15 \%$ rate. However, the tax burden can be reduced if the dividend payee is a resident of the country that signed a double tax treaty with the RS. Non-resident individuals have to prove residency of the country that signed the treaty in order to apply lower tax rates than those agreed upon in signed treaties.

Dividends that legal entities receive are taxed in accordance with Corporate Profit Tax Law (The Official 
Gazette of the RS, no. 95/2018). According to article 25, dividends that resident legal entities receive are exempt from dividend tax.

In the context of non-resident legal entities as dividend payees, they are generally taxed at $20 \%$ rate applied on gross dividend. Similar to taxation of non-resident individuals, tax burden can be reduced if the legal entity is resident of the country that signed a double tax treaty with the RS, assuming that the non-resident legal entity proves residency of the country that signed treaty.

It is interesting to note that dividend payment to residents of tax havens is also taxed at a $20 \%$ rate. According to article 40 of the Corporate Profit Tax Law, payments to legal entities that are residents of tax havens, are taxed at a $25 \%$ rate. However, these payments do not refer to dividend payment, but to payments of royalties, interest, rent and service fees.

A potential problem of such a dividend taxation system can be found in the possibility for money transfer to countries with preferential tax system (tax havens). Namely, the RS has signed double tax treaties with the Netherlands, Luxembourg, Republic of Ireland and Switzerland, which are countries that are considered as potential tax havens or conduit countries for money transfer to tax havens (Garcia-Bernardo, Fichtner, Takes \& Heemskerk, 2017).

Dividend tax is a kind of withholding taxes, which means that a dividend payer must calculate and pay dividend tax on behalf of a dividend payee. Dividend tax is paid at the moment of net dividend payment.

\subsection{Comparison of tax treatment of dividends and capital gains}

Capital gains taxation is prescribed by a similar law as dividend taxation. Individuals pay capital gains tax in accordance with articles 72-80 of Personal Income Tax Law, while legal entities pay capital gains tax as part of profit taxation, in accordance with articles 27-31 of Corporate Profit Tax Law.

Resident investors' capital gains are taxed at a $15 \%$ rate that is similar to general individuals dividend tax. Therefore, it might be concluded that resident individual investors are indifferent to dividends or capital gains. However, they may have tax preferences to capital gains due to, at least, two reasons:

- tax regulation of the RS allows offsetting of capital gains with capital losses and capital loss carryforward to offset future capital gains in the period of five years (according to article 78 of the Personal Income Tax Law and article 30 of Corporate Profit Tax Law), which enables effective capital gains tax rate to be considerably reduced and

- capital gains tax liability arises at the moment of sale of the shares, which potentially represents significant deferral of tax liabilities - however, such argument should be considered carefully, considering a possibility of future capital gains tax rate increase.

Provisions on offsetting capital gains with capital losses, timing of capital gains tax payment and capital gains tax rate are similar for taxation of capital gains of resident legal entities. In general, it should mean that, primarily resident, corporate investors should have tax preferences on dividends compared to capital gains, since they are exempt from dividend tax.

Regarding non-resident investors, tax preferences depend on individual case. In general, both dividends and capital gains that non-residents achieve are taxed at $20 \%$ for legal entities and $15 \%$ for individuals, whereby the mentioned possibilities on payment timing and offsetting capital gains with capital losses exist. Therefore, in general case, these groups of investors should tend to capital gains. However, tax preferences of nonresidents might be under influence of terms from double tax treaties that the RS signed with other countries.

\section{Empirical Research}

\subsection{Context analysis, methodology and sample}

The research in this paper captured dividends of public stock companies listed on the Belgrade Stock Exchange, paid between 2013 and 2018. Corporate income tax and dividend tax rates were constant during the observed period. An important problem lies in the fact that most of the public stock companies (even companies in the main stock indices) in the RS do not, at least sporadically, pay dividends. Zakic (2016) explains this by poor shareholding culture in the RS, high ownership concentration and global economic 
crisis. In addition, listed companies in the RS are significantly financed with internal funds due to undeveloped stock market and expensive bank loans (Malinic, Dencic-Mihajlov \& Ljubenovic, 2013).

The largest public stock company in Serbia - NIS, Novi Sad - regularly paid dividends between 2013 and 2019 with 0.25 dividend payout ratio. On the other hand, this company did not pay dividends in 2011 and 2012, partially due to pre-tax losses in previous years. A vast majority of other public stock companies did not pay dividends on regular basis. In fact, many of them opt for share repurchases due to their preferential tax treatment over dividend payments. For example, one public stock company - Dijamant, Zrenjanin published over fifty reports on share repurchases in the period between 2012 and 2017.

Using a panel regression analysis, the paper examins the impact of corporate income tax burden (proxied with Accounting effective tax rate - AcETR and Current effective tax rate - CuETR) on dividend policy (proxied with dividend payout ratio - DPR), controlling for some firm-specific variables. Following prior research (Amidu \& Abor, 2006; Denis \& Osobov, 2008; Gill et al., 2010; Mehta, 2012), profitability (PROF), leverage (DEBTR) and size (SIZE) proxies as well as P/E ratio (PER) as control variablesare used. Some authors (Mehta, 2012; Maniagi, Ondiek, Musiega, Maokomba \& Egessa, 2013) use liquidity as control variable assuming that companies with higher liquidity reserves pay higher dividends. In our sample, liquidity (proxied with Current ratio) and leverage (proxied with DEBTR) appear to have a strong correlation (Pearson's $r=-$ 0.647 ) so liquidity is not used in order to avoid multicollinearity problems. Although not tabulated, regression results do not differ significantly if DEBTR is substituted with Current ratio in formulated research model. We have also used industry dummies (according to Eurostat industry classification) to control potential industry variations in dividend payout ratio. Table 1 presents definitions of employed variables.

Table 1: Definitions of employed variables

\begin{tabular}{|c|c|c|}
\hline Label & Variable name & Formula \\
\hline DPR & Dividend payout ratio & Gross dividend per share / Net income per share \\
AcETR & Accounting effective tax rate & [(Current tax expense + Deferred tax expense/benefit) / \\
CuETR & Current effective tax rate & Pre-tax income] $\times 100$ \\
PROF & Return on assets & (Current tax expense / Pre-tax income $) \times 100$ \\
DEBTR & Debt ratio & (Net income / Total assets) $\times 100$ \\
SIZE & Company size & Total liabilities / Total assets \\
PER & Price-to-Earnings ratio & Natural logarithm of total assets \\
\hline
\end{tabular}

Source: Authors' calculation. Note: For dividend paid in year $t$, financial data is retrieved from financial statements for year $\mathrm{t}-1$ (share market price is retrieved at the end of year $\mathrm{t}-1$ ), since dividend in year $\mathrm{t}$ is paid on the basis of previous year net income.

In the line with defined variables, it is possible to formulate the following regression model:

$$
D P R_{i, t}=\beta_{0}+\beta_{1} E T R_{i, t}+\beta_{2} P R O F_{i, t}+\beta_{3} D E B T R_{i, t}+\beta_{4} S I Z E_{i, t}+\beta_{5} P E R_{i, t}+\varepsilon_{i, t}
$$

where ETR refers to AcETR and CuETR.

The research has used tests of equality of independent groups in order to examine whether the largest shareholder's dividend tax bracket influences the DPR. In other words, these tests examine significance of the difference in DPR between companies whose largest shareholders are low taxed and companies whose largest shareholders are high taxed. Due to the lack of normal distribution of DPR, non-parametric MannWhitney tests are used.

The sample did not capture either interim dividends or dividend payments of loss companies. The final sample represents unbalanced panel data with 23 companies and 92 observations. Although the number of observations is relatively small, according to Tabachnick \& Fidell $(2007, \mathrm{p} .123)$, the size of the sample is appropriate for running a regression analysis. Following their formula $(\mathrm{N}>50+8 \mathrm{~m}$, where $\mathrm{N}$ is minimum sample size and $\mathrm{m}$ is a number of predictors), the minimum sample size in our paper is 90 .

For the purposes of Mann-Whitney tests, there are 16 withdrawn observations due to the unavailability of clear ownership structure. The final sample in this case contains 76 observations. Furtherly, due to the lack of the data on dividend payments before 2013, it was not possible to examine whether tax rate changes in 2012 and 2013 influenced DPR. 
Financial data on sampled companies and ownership structure data are retrieved from websites of The Serbian Business Registers Agency (www.apr.gov.rs) and Belgrade Stock Exchange (www.belex.rs).

\subsection{Research results}

Presentation of research results contains descriptive statistics, correlation and regression analysis as well as Mann-Whitney tests results. Table 2 shows descriptive statistics.

Table 2: Descriptive Statistics

\begin{tabular}{|l|c|c|c|c|c|c|}
\hline \multicolumn{1}{|c|}{$\mathbf{n = 9 2}$} & Mean & Minimum & Median & Maximum & $\begin{array}{c}\text { Standard } \\
\text { deviation }\end{array}$ & $\begin{array}{c}\text { Coefficient of } \\
\text { variation }\end{array}$ \\
\hline DPR & 0.457 & 0.007 & 0.385 & 1.634 & 0.343 & 0.749 \\
AcETR & $8.631 \%$ & $-2.110 \%$ & $8.535 \%$ & $23.586 \%$ & $6.801 \%$ & 0.788 \\
CuETR & $8.629 \%$ & $0.000 \%$ & $7.272 \%$ & $55.046 \%$ & $8.317 \%$ & 0.964 \\
PROF & $9.462 \%$ & $0.167 \%$ & $7.387 \%$ & $31.421 \%$ & $6.642 \%$ & 0.702 \\
DEBTR & 0.272 & 0.023 & 0.217 & 0.808 & 0.190 & 0.700 \\
SIZE & 14.849 & 9.930 & 14.689 & 19.807 & 1.768 & 0.119 \\
PER & 9.385 & 0.259 & 6.111 & 70.640 & 12.249 & 1.305 \\
\hline
\end{tabular}

Source: Authors' calculation. Note: ${ }^{*}{ }^{* *}$, and ${ }^{* * *}$ indicate significance at the $0.1,0.05$, and 0.01 levels, respectively.

DPR is higher than one in seven observations, meaning that companies paid a net income plus retained earnings as dividends. Only six of 23 sampled companies paid dividends in each observed year, which indicates a lack of regularity of dividend payments in the RS.

AcETR and CuETR are, on the average, significantly lower than statutory tax rate of $15 \%$. AcETR is negative in ten observations due to deferred tax benefit higher than current income tax and deferred tax expense combined, while in five observations was $0 \%$. This rate was higher than $15 \%$ in 24 observations. On the other hand, CuETR was $0 \%$ in 24 observations and higher than 15\% in 23 observations.

There are ten observations with PROF higher than $20 \%$. Sampled companies are, on the average, dominantly financed with own sources since average DEBTR is relatively low. In addition, SIZE is the variable with lowest variation, while PER is the variable with highest variation.

Table 3: Correlation matrix

\begin{tabular}{|l|c|c|c|c|c|c|c|}
\hline \multicolumn{1}{|c|}{$\mathbf{n}=92$} & DPR & AcETR & CuETR & PROF & DEBTR & SIZE & LIQ \\
\hline DPR & 1.000 & & & & & & \\
AcETR & -0.067 & 1.000 & & & & & \\
CuETR & -0.032 & $* \star * 0.769$ & 1.000 & & & & \\
PROF & 0.170 & -0.151 & $*-0.174$ & 1.000 & & & \\
DEBTR & $* *-0.225$ & $* 0.179$ & 0.083 & $* * *-0.311$ & 1.000 & & \\
SIZE & $* *-0.242$ & -0.020 & -0.106 & -0.141 & $* * 0.205$ & 1.000 & \\
LIQ & $* * * 0.399$ & -0.041 & $* * 0.250$ & $* *-0.229$ & -0.162 & -0.063 & 1.000 \\
\hline
\end{tabular}

Source: Authors' calculation. Note: * ${ }^{* *}$, and ${ }^{* *}$ indicate significance at the $0.1,0.05$, and 0.01 levels, respectively

Pearson's correlation matrix, presented in Table 3, shows that there is no significant correlation between effective tax rates (AcETR or CuETR) and DPR. On the other hand, significant and high positive correlation appears between AcETR and CuETR. There is no high correlation among predictors, so problems with multicollinearity are not expected.

Table 4 presents panel regression results with Random-Effects (RE) regression models reported. FixedEffects regression (and, therefore, Hausman test) has not been employed due to time-invariant variables in the model and near singular matrix problem. Furtherly, Breusch-Pagan LM test showed that RE regression model is more appropriate than Ordinary Least Squares model.

Regression results show that formulated regression model explains the important portion of DPR variation. In addition, Variance Inflation Factors are lower than 10 for each variable in each regression model, so multicollinearity problems are not expected. 
The impact of effective tax rates on DPR is extremely weak and negative, though insignificant, implying that companies in the RS design their dividend policies regardless of the corporate income tax expense. It is possible that companies do not pay attention to corporate income tax since corporate income tax burden in sampled companies is relatively low, i.e., considerably lower than statutory tax rate. Furtherly, it is clear that companies rely only on net income when designing a dividend policy.

Such results of regression analysis can be partially explained with the fact that there are companies that paid the equal gross dividend (Zitosrem, Indjija, 10 Serbian dinars per share) or had the same DPR in each observed year (NIS, Novi Sad, 0.250) regardless of the variation of effective tax rates.

Table 4: Random-Effects Regression analysis results

\begin{tabular}{|l|c|c|}
\hline \multicolumn{1}{|c|}{$\mathbf{n = 9 2}$} & \multicolumn{2}{|c|}{ Dependent variable: DPR } \\
\hline \multirow{2}{*}{ Intercept } & 0.943 & 0.805 \\
& $(1.572)$ & $(1.362)$ \\
AcETR & -0.006 & \\
CuETR & $(-1.054)$ & -0.001 \\
& & $(-0.212)$ \\
PROF & $* *-0.012$ & $* *-0.010$ \\
& $(-2.533)$ & $(-2.189)$ \\
DEBTR & $*-0.396$ & -0.343 \\
& $(-1.707)$ & $(-1.512)$ \\
SIZE & -0.023 & -0.017 \\
& $(-0.600)$ & $(-0.431)$ \\
PER & $* * 0.005$ & $* * 0.005$ \\
Industry dummies & $(2.348)$ & $(2.002)$ \\
Adjusted $R^{2}$ & Yes & Yes \\
F-value & 0.147 & 0.140 \\
& $* * 2.427$ & $* * 2.349$ \\
\hline
\end{tabular}

Source: Authors' calculation. Beta coefficients in front of parentheses, t-values in parentheses; note: * **, and *** indicate significance at the $0.1,0.05$, and 0.01 levels, respectively.

Among predictors, the impact of PROF on DPR is negative and statistically significant. In other words, the more profitable the company is, the DPR is lower. SIZE does not appear to have significant impact of DPR, while the impact of DEBTR on DPR is significant only in first regression model. Finally, PER has a significant positive impact of DPR in each regression model, since companies with higher PER also have higher DPR, supporting the finding of Mehta (2012).

The presented regression results, with some insignificant variables and contradicting to some prior research, support attitudes that dividend puzzle still represents a corporate finance mystery. Despite decades of worldwide research, the dividend policy is still not well explained (Baker, Powell \& Veit, 2002), although determinants of dividend policy tend to be constant over the time (Baker \& Powell, 2000). On the other hand, Jabbouri \& El Attar (2018) argue that dividend policy research needs important improvements given that prior research is inconclusive, contradicting and not universally accepted.

The fact that some variables do not impact the dividend policy is not surprising given an undeveloped stock market of the RS and a low number of stock companies and dividend payments. In nearly similar circumstances, Mehta (2012), Rehman (2012), Maniagi et al. (2013) and Yusof \& Ismail (2016) report a high number of insignificant predictors of dividend policy in the United Arab Emirates, Pakistan, Kenya and Malaysia, respectively.

In the next part of the research, Mann-Whitney tests have been conducted in order to examine whether dividend tax bracket of the largest shareholder impacts DPR. Table 6 presents the results of these tests. 
Table 5: Results of Mann-Whitney tests

\begin{tabular}{|c|c|c|c|c|}
\hline \multicolumn{5}{|c|}{ Panel A. Difference between tax exempt and taxed largest shareholders } \\
\hline \multicolumn{2}{|c|}{ Number of observations } & \multirow{2}{*}{$\begin{array}{c}\text { Mann-Whitney } \\
U\end{array}$} & \multirow[b]{2}{*}{ Z } & \multirow[b]{2}{*}{ p-value } \\
\hline Dividend tax rate at $0 \%$ & $\begin{array}{l}\text { Dividend tax rate higher } \\
\text { than } 0 \%\end{array}$ & & & \\
\hline 33 & 43 & 623.000 & -0.907 & 0.365 \\
\hline \multicolumn{5}{|c|}{ Panel B. Difference between low taxed and high taxed largest shareholders } \\
\hline \multicolumn{2}{|c|}{ Number of observations } & \multirow{2}{*}{$\begin{array}{c}\text { Mann-Whitney } \\
\text { U }\end{array}$} & \multirow[b]{2}{*}{ Z } & \multirow[b]{2}{*}{ p-value } \\
\hline $\begin{array}{c}\text { Dividend tax rate from } 0 \% \text { to } \\
5 \%\end{array}$ & $\begin{array}{l}\text { Dividend tax rate higher } \\
\text { than } 5 \%\end{array}$ & & & \\
\hline \begin{tabular}{|l|l}
47 &
\end{tabular} & 29 & 580.000 & -1.085 & 0.278 \\
\hline
\end{tabular}

Source: Authors' calculation.

Research results show that companies whose largest shareholders are exempt from dividend tax have higher DPR compared to companies whose largest shareholders pay dividend tax, which is in accordance with tax avoidance motive. However, this difference is not statistically significant (Panel A). On the other hand, companies whose largest shareholders are low taxed have lower DPR compared to companies whose largest shareholders are high taxed, which is contrary to tax avoidance motive. However, this difference is not statistically significant either (Panel B).

According to Mann-Whitney tests, the dividend policy of the companies in the RS is independent from the dividend tax bracket of the largest shareholder. Furtherly, in terms of foreign-owned companies, it is worth noting that dividends are paid only when the largest shareholder is a resident of a country that signed a double tax treaty with the RS, such as Germany, Slovenia and Russia. Due to the treaty provisions, the dividend tax rate in these observations is reduced from $20 \%$ to $5 \%, 10 \%$ or $15 \%$.

\section{Conclusion}

The research in this paper captured 92 dividend payments of companies listed on the Belgrade Stock Exchange between 2013 and 2018 in order to examine whetherthe corporate income tax and the dividend tax impact the dividend policy of companies in the RS.

The results of the panel regression analysis show that the corporate income tax expense (proxied with Accounting and Current effective tax rates) does not impact DPR. Such results indicate that companies do not consider the corporate income tax a burden when deciding on dividends, mostly due to the effective tax rates being considerably lower than the statutory tax rate of $15 \%$. These results are contrary to the results of Amidu \& Abor (2006) and Gill et al. (2010). Therefore, the first research hypothesis is rejected.

Mann-Whitney tests show that the dividend tax does not impact DPR. There is no significant difference in the DPR between companies whose largest shareholder is high taxed and companies whose shareholder is low taxed. These findings can be explained with relatively low dividend tax rates. Therefore, the second research hypothesis is rejected. Furtherly, the research shows that foreign-owned companies pay dividends only if the largest shareholder is a resident of the country that signed a double tax treaty with the RS.

In general, taxation and other predictors explain a relatively small portion of DPR variation. This is in line with Baker et al. (2002) and Jabbouri \& El Attar (2018) about the dividend policy as a mysterious corporate finance topic.

The presented research results have some limitations. First, the sample size is insufficient though it is limited with rare dividend payments in the RS. Second, it is possible that the research results would be different if the number of sampled companies or sampling period is changed. Finally, the financial data are retrieved from statutory financial statements - it is possible that results would be different if consolidated data were used.

The future research should include other South Eastern European countries in order to compare the obtained results. In addition, it is useful to examine the tax treatment of dividend payment and share repurchase along with the treatment of dividends and capital gains.

\section{Acknowledgements}

This paper is part of the project III 47005, financed by the Ministry of Education, Science and Technological Development of the Republic of Serbia. 


\section{REFERENCES}

[1] Alli, K., Khan, Q., \& Ramirez, G. (1993). Determinants of Corporate Dividend Policy: A Factorial Analysis. The Financial Review, 28(4), 523-547. DOI: 10.1111/j.1540-6288.1993.tb01361.x.

[2] Amidu, M., \& Abor, J. (2006). Determinants of Dividend Payout Ratios in Ghana. The Journal of Risk Finance, 7(2), 136-145. DOI: 10.1108/15265940610648580.

[3] Baker, H., \& Powell, G. (1999). How Corporate Managers View Dividend Policy. Quarterly Journal of Business and Economics, 38(2), 17-35.

[4] Baker, H., \& Powell, G. (2000). Determinants of Corporate Dividend Policy: A Survey of NYSE Firms. Financial Practice and Education, 10(1), 29-40.

[5] Baker, M., \& Wurgler, J. (2004). A Catering Theory of Dividends. Journal of Finance, 59(3), 1125-1165. DOI: $10.1111 / \mathrm{j} .1540-6261.2004 .00658 . x$.

[6] Baker, H., Powell, G., \& Veit, E. (2002). Revisiting the Dividend Puzzle: Do All of the Pieces Now Fit? Review of Financial Economics, 11(4), 241-261. DOI: 10.1016/S1058-3300(02)00044-7.

[7] Balachandran, B., Khan, A., Mather, P., \& Theobald, M. (2019). Insider Ownership and Dividend Policy in an Imputation Tax Environment. Journal of Corporate Finance, 54(1), 153-167. DOI: 10.1016/j.jcorpfin.2017.01.014.

[8] Benavides, J., Berggrun, L., \& Perafan, H. (2016). Dividend Payout Policies: Evidence from Latin America. Finance Research Letters, 17(1), 197-210. DOI: 10.1016/j.frl.2016.03.012.

[9] Bostanci, F., Kadioglu, E., \& Sayilgan, G. (2018). Determinants of Dividend Payout Decisions: A Dynamic Panel Data Analysis of Turkish Stock Market. International Journal of Financial Studies, 6(4), 1-16. DOI: 10.3390/ijfs6040093.

[10] Brown, J., Liang, N., \& Weisbenner, S. (2007). Executive Financial Incentives and Payout Policy: Firm Responses to the 2003 Dividend Tax Cut. The Journal of Finance, 62(4), 1935-1965. DOI: 10.1111/j.15406261.2007.01261.x.

[11] Chaplinsky, S., \& Seyhun, H. (1990). Dividends and Taxes: Evidence on Tax-Reduction Strategies. The Journal of Business, 63(2), 239-260. DOI: 10.1086/296504.

[12] Chen, Z., Cheung, Y., Stouraitis, A., \& Wong, A. (2005). Ownership Concentration, Firm Performance, and Dividend Policy in Hong Kong. Pacific-Basin Finance Journal, 13(4), 431-449. DOI: 10.1016/j.pacfin.2004.12.001.

[13] Chetty, R., \& Saez, E. (2010). Dividend and Corporate Taxation in an Agency Model of the Firm. American Economic Journal: Economic Policy, 2(3), 1-31. DOI: 10.1257/pol.2.3.1.

[14] Dahlquist, M., Robertsson, G., \& Rydqvist, K. (2014). Direct Evidence of Dividend Tax Clienteles. Journal of Empirical Finance, 28(1), 1-12. DOI: 10.1016/j.jempfin.2014.05.003.

[15] Denis, D., \& Osobov, I. (2008). Why Do Firms Pay Dividends? International Evidence on the Determinants of Dividend Policy. Journal of Financial Economics, 89(1), 62-82. DOI: 10.1016/j.jineco.2007.06.006.

[16] Desai, M., \& Jin, L. (2011). Institutional Tax Clienteles and Payout Policy. Journal of Financial Economics, 100(1), 68-84. DOI: 10.1016/j.jfineco.2010.10.013.

[17] Dhaliwal, D., Erickson, M., \& Trezevant, R. (1999). A Test of the Theory of Tax Clienteles for Dividend Policies. National Tax Journal, 52(2), 179-194.

[18] Dhaliwal, D., Gleason, C., \& Mills, L. (2004). Last-Chance Earnings Management: Using the Tax Expense to Meet Analysts' Forecasts. Contemporary Accounting Research, 21 (2), 431-459. DOI: 10.1506/TFVVUYT1-NNYT-1YFH.

[19] Franc-Dabrowska, J., Madra-Sawicka-M., \& Ulrichs, M. (2020). Determinants of Dividend Payout Decisions - The Case of Publicly Quoted Food Industry Enterprises Operating in Emerging Markets. Economic Research, 33(1), 1108-1129. DOI: 10.1080/1331677X.2019.1631201.

[20] Frank, M., \& Rego, S. (2006). Do Managers Use the Valuation Allowance Account to Manage Earnings around Certain Earnings Targets? The Journal of the American Taxation Association, 28(1), 43-65. DOI: 10.2308/jata.2006.28.1.43.

[21] Garcia-Bernardo, J., Fichtner, J., Takes, F., \& Heemskerk, E. (2017). Uncovering Offshore Financial Centers: Conduits and Sinks in the Global Corporate Ownership Network. Scientific Reports, 7(1), 110. DOI: $10.1038 / \mathrm{s} 41598-017-06322-9$.

[22] Gill, A., Biger, N., \& Tibrewala, R. (2010). Determinants of Dividend Payout Rations: Evidence from United States. The Open Business Journal, 3(1), 8-14. DOI: 10.2174/1874915101003010008.

[23] Gordon, M. (1959). Dividends, Earnings, and Stock Prices. The Review of Economics and Statistics, 41(2), 99-105. DOI: 10.2307/1927792.

[24] Grullon, G., \& Michaely, R. (2002). Dividends, Share Repurchases, and the Substitution Hypothesis. The Journal of Finance, 57(4), 1649-1684. DOI: 10.1111/1540-6261.00474.

[25] Hanlon, M., \& Heitzman, S. (2010). A Review of Tax Research. Journal of Accounting and Economics, 50(2-3), 127-178. DOI: 10.1016/j.jacceco.2010.09.002. 
[26] Harada, K., \& Nguyen, P. (2011). Ownership Concentration and Dividend Policy in Japan. Managerial Finance, 37(4), 362-379. DOI: 10.1108/03074351111115313.

[27] Jabbouri, I., \& El Attar, A. (2018). The Dividend Paradox: A Literature Review. International Journal of Markets and Business Systems, 3(3), 197-221. DOI: 10.1504/IJMABS.2018.093292.

[28] Jacob, M., \& Michaely, R. (2017). Taxation and Dividend Policy: The Muting Effect of Agency Issues and Shareholder Conflicts. The Review of Financial Studies, 30(9), 3176-3222. DOI: 10.1093/rfs/hhx041.

[29] Khan, T. (2006). Company Dividends and Ownership Structure: Evidence from UK Panel Data. The Economic Journal, 116(510), 172-189. DOI: 10.1111/j.1468-0297.2006.01082.x.

[30] Litzenberger, R., \& Ramaswamy, K. (1979). The Effect of Personal Taxes and Dividends on Capital Asset Prices: Theory and Empirical Evidence. Journal of Financial Economics, 7(2), 163-195. DOI: 10.1016/0304-405X(79)90012-6.

[31] Maier, C., \& Schanz, D. (2016). Convergence of Dividend and Capital Gains Taxation in the European Union from 1990 to 2015. Intertax, 44(12), 913-937.

[32] Malinic, D., Dencic-Mihajlov, K., \& Ljubenovic, E. (2013). The Determinants of Capital Structure in Emerging Capital Markets: Evidence from Serbia. European Research Studies, 16(2), 98-119.

[33] Mancinelli, L., \& Ozcan, A. (2006). Ownership Structure and Dividend Policy: Evidence from Italian Firms. The European Journal of Finance, 12(3), 265-282. DOI: 10.1080/13518470500249365.

[34] Maniagi, M., Ondiek, A., Musiega, D., Maokomba, C., \& Egessa, R. (2013). Determinants of Dividend Payout Policy Among Non-Financial Firms on Nairobi Securities Exchange, Kenya. International Journal of Scientific \& Technology, 2(10), 253-266.

[35] Mehta, A. (2012). An Empirical Analysis of Determinants of Dividend Policy - Evidence from the UAE Companies. Global Review of Accounting and Finance, 3(1), 18-31.

[36] Miller, M., \& Modigliani, F. (1961). Dividend Policy, Growth, and the Valuation of Shares. The Journal of Business, 34(4), 411-433. DOI: 10.1086/294442.

[37] Rehman, A. (2012). Determinants of Dividend Payout Ratio: Evidence from Karachi Stock Exchange (KSE). Journal of Contemporary Issues in Business Research, 1(1), 20-32.

[38] Short, H., Zhang, H., \& Keasey, K. (2002). The Link between Dividend Policy and Institutional Ownership. Journal of Corporate Finance, 8(2), 105-122. DOI: 10.1016/S0929-1199(01)00030-X.

[39] Singla, H., \& Samanta, P. (2019). Determinants of Dividend Payout of Construction Companies: A Panel Data Analysis. Journal of Financial Management of Property and Construction, 24(1), 19-38. DOI: 10.1108/jfmpc-06-2018-0030.

[40] Stakic, N., Jovancai, A., \& Kapor, P. (2016). The Efficiency of the Stock Market in Serbia. Journal of Policy Modeling, 38(1), 156-165. DOI: 10.1016/j.jpolmod.2015.12.001.

[41] Tabachnick, B., \& Fidell, L. (2007). Using Multivariate Statistics, 5th edition. Boston: Pearson Education.

[42] Yusof, Y., \& Ismail, S. (2016). Determinants of Dividend Policy of Public Listed Companies in Malaysia. Review of International Business and Strategy, 26(1), 88-99. DOI: 10.1108/RIBS-02-2014-0030.

[43] Zakic, V. (2016). Politika dividendi akcionarskih preduzeća u Srbiji. Finansije, 71(1-6), 79-92.

[44] Zivkovic, B., \& Minovic, J. (2010). Illiquidity of Frontier Financial Market: Case of Serbia. Panoeconomicus, 57(3), 349-367. DOI: 10.2298/PAN1003349Z.

Received: 2020-12-06

Revisions requested: 2021-02-09

Revised: 2021-02-14

Accepted: 2021-03-23

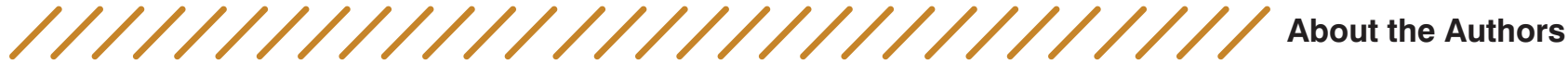

\section{Biljana Jovković}

University of Kragujevac, Faculty of Economics, Serbia bjovkovic@kg.ac.rs

Biljana Jovković is an Associate Professor at the Faculty of Economics, University of Kragujevac, teaching courses in Auditing and Accounting of Financial Organizations. She obrtained her PhD degree in 2012 in the field of auditing of financial statements of insurance companies from the Faculty of Economics in Kragujevac and earned his Master's degree in 2007 from the Faculty of Economics in Belgrade. She graduated in 2002 from the Faculty of Economics in Kragujevac. She is the author or co-author of more than 30 published papers and has participated in several scientific conferences.

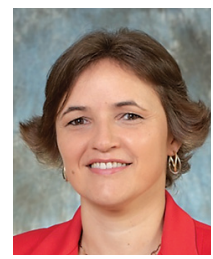




\section{Stefan Vržina \\ University of Kragujevac, Faculty of Economics, Serbia stefan.vrzina@kg.ac.rs}

Stefan Vržina is a Research Assistant at the Faculty of Economics, University of Kragujevac, teaching courses in Business Finance and Financial Analysis and Planning. He is a PhD student at the Faculty of Economics in Kragujevac. In 2017, he received his master's degree, while in 2016 he graduated from the same faculty.

$\mathrm{He}$ is the author of several published papers and has participated in international scientific conferences. The main fields of his research interest are corporate finance, tax accounting and financial analysis. 